Article

\title{
Improvement of Saccharification and Delignification Efficiency of Trichoderma reesei Rut-C30 by Genetic Bioengineering
}

\author{
Raja Mohan Gopalakrishnan ${ }^{1}$, Tamilvendan Manavalan ${ }^{1}$, Janani Ramesh ${ }^{2} \mathbb{}$, \\ Kalaichelvan Puthupalayam Thangavelu ${ }^{1, *}$ and Klaus Heese ${ }^{3, * \text { DD }}$ \\ 1 Centre for Advanced Studies in Botany, University of Madras, Guindy Campus, Chennai, Tamil Nadu 600 \\ 025, India; rgrajamohan@yahoo.com (R.M.G.); tamilvendan@gmail.com (T.M.) \\ 2 Department of Medical Biochemistry, Dr ALM Postgraduate Institute of Biomedical Sciences, University of \\ Madras, Chennai, Tamil Nadu 600 113, India; rjjananiramesh95@gmail.com \\ 3 Graduate School of Biomedical Science and Engineering, Hanyang University, 222 Wangsimni-ro, \\ Seongdong-gu, Seoul 133-791, Korea \\ * Correspondence: ptkalai2003@yahoo.com (K.P.T.); klaus@hanyang.ac.kr (K.H.)
}

Received: 12 December 2019; Accepted: 22 January 2020; Published: 23 January 2020

\begin{abstract}
Trichoderma reesei produces various saccharification enzymes required for biomass degradation. However, the lack of an effective lignin-degrading enzyme system reduces the species' efficiency in producing fermentable sugars and increases the pre-treatment costs for biofuel production. In this study, we heterologously expressed the Ganoderma lucidum RMK1 versatile peroxidase gene (vp1) in the Rut-C30 strain of T. reesei. The expression of purified $6 \times$ His-tag-containing recombinant G. lucidum-derived protein (rVP1) was confirmed through western blot, which exhibited a single band with a relative molecular weight of $39 \mathrm{kDa}$. In saccharification and delignification studies using rice straw, the transformant (tVP7, T. reesei Rut-C30 expressing G. lucidum-derived rVP1) showed significant improvement in the yield of total reducing sugar and delignification, compared with that of the parent $T$. reesei Rut-C30 strain. Scanning electron microscopy (SEM) of tVP7-treated paddy straw showed extensive degradation of several layers of its surface compared with the parent strain due to the presence of G. lucidum-derived rVP1. Our results suggest that the expression of ligninolytic enzymes in cellulase hyperproducing systems helps to integrate the pre-treatment and saccharification steps that may ultimately reduce the costs of bioethanol production.
\end{abstract}

Keywords: bioethanol; biomass degradation; delignification; Ganoderma lucidum; scanning electron microscope; Trichoderma reesei; versatile peroxidase

\section{Introduction}

Lignocellulosic materials such as agricultural waste and crop residue, including rice straw, corn straw, cotton seed hair, cassava stem, and wheat straw, among others, have become feedstock for second-generation bioethanol production [1]. Extracting the maximum benefits from bioethanol production will require maximal utilization of lignocellulose materials [2], which consist of lignin and carbohydrate molecules such as cellulose, hemicellulose, pectin, etc. [3]. The presence of lignin hinders digestive enzymes' access to cellulose and hemicellulose, which upon digestion serve as substrates for bioethanol production. The degradation of lignin is therefore essential for gaining access to the full contents of carbohydrates in efficient bioethanol production [4,5]. Generally, bioethanol production involves the preparation of feedstock (pre-treatment), digestion of cellulose and hemicelluloses into fermentable sugars (saccharification), and the conversion of fermentable sugars to bioethanol (fermentation) [6,7]. The pre-treatment step, which determines the quantity of fermentable sugars, 
and thus the quantity of bioethanol produced, improves the efficiency of lignocelluloses hydrolysis by separating cellulose from hemicellulose and lignin compaction [8,9]. Among the available methods, the physical methods are energy-consuming and the chemical methods are environmentally toxic, leaving biological treatment as the most viable pre-treatment option [9,10]. Integration of pre-treatment and saccharification using biological treatments is the preferred contemporary choice.

White-rot fungi represent more than $90 \%$ of wood-rot fungi and are the most efficient organisms in degrading lignin. Notable members of the group include Ganoderma spp., Lentinula edodes, Phlebia radiata, and Pleurotus spp. [11]. Lignin degradation by white-rot fungi is due to the production of various classes of lignin-modifying enzymes such as laccase (Lac), manganese peroxidase (MnP), lignin peroxidase (LiP), and versatile peroxidase (VP) [12-14]. High-redox-potential (0.8-1.2 V) enzymes, such as peroxidases, are more suitable for lignin degradation in terms of efficiency [15]. In this regard, VP is unique due to its high redox potential on the one hand and its substrate diversity on the other. Unlike $\mathrm{MnP}$ or LiP, it can oxidize both low- and high-redox compounds without an external mediator [16,17]. These advantages have drawn attention to delignification applications using VP [18,19].

Trichoderma reesei, the sexual anamorph of Hypocrea jecorina, is an industrially noteworthy soft-rot fungus known for its hyperproduction of cellulases and hemicellulases, which makes it an effective tool for biomass conversion industries [20]. It produces nearly nine different endoglucanases (EG) and two different cellobiohydrolases $(\mathrm{CBH})$, all extracellularly. The cellobiohydrolases constitute nearly $85 \%$ of secreted proteins in T. reesei under cellulase-inducing conditions [21,22]. However, although T. reesei is capable of degrading crystalline cellulose, it is inefficient in degrading lignin [23]. The introduction of high-redox-potential enzymes, especially VP, should help the strain finding potential applications in biofuel industries. A successful attempt has been made to heterologously express a $P$. radiata laccase gene in $T$. reesei, which produced $20 \mathrm{mg} / \mathrm{L}$ of active laccase in fermentation at a small scale [24]. Another study yielded 28.6-fold higher laccase production by expressing a laccase gene from Pleurotus ostreatus in the T. reesei strain Tu6 [25]. Recently, a thermotolerant laccase from Pycnoporus sanguineus was expressed in T. reesei with a yield of $17.7 \mathrm{U} / \mathrm{mL}$ [26]. These studies on the expression of ligninolytic enzymes in $T$. reesei suggest that $T$. reesei can serve as a compatible host for effective ligninolytic enzymes production. Satisfactory protein secretion and post-translational modifications of $T$. reesei would make it a useful expression host, apart from the effortless downstream processing it offers [27]. In this investigation, we made an attempt to apply the engineered Pcbh1 promoter to heterologously express the RMK1 versatile peroxidase ( $v p 1$ ) gene from Ganoderma lucidum, an organism that houses different thermostable ligninolytic enzymes [28], into the T. reesei Rut-C30 strain to improve the biomass hydrolysis efficiency of the host organism. Upon generation of the transformant tVP7 ( $T$. reesei Rut-C30 expressing G. lucidum-derived protein-rVP1) and rVP1 expression, we characterized purified G. lucidum-derived rVP1 and analyzed its delignification and saccharification efficiency using the transformant tVP7 while comparing it with its parent strain T. reesei Rut-C30.

\section{Materials and Methods}

\subsection{Microbial Strains and Growth Conditions}

Ganoderma lucidum RMK1 (accession number MH553170), isolated from Kumarakom Bird Sanctuary $\left(9.6274^{\circ} \mathrm{N}, 76.4286^{\circ} \mathrm{E}\right)$ at Kumarakom, Kerala, India, was used as a source for the vp1 gene (cDNA). Trichoderma reesei Rut-C30 (ATCC 56765) was used as the heterologous host for expression of the G. lucidum-derived vp1 gene (JGI; Protein ID: 116056). Potato dextrose agar (PDA) was used to maintain fungal cultures throughout the study. Escherichia coli Top10-competent cells (Thermo Fisher Scientific, Waltham, MA, USA) cultivated in Luria-Bertani (LB) broth (HiMedia Laboratories Pvt. Ltd., Mumbai, Maharashtra, India) at $37^{\circ} \mathrm{C}$ and $200 \mathrm{rpm}$ overnight using $100 \mathrm{mg} / \mathrm{mL}$ kanamycin as a selection marker were used to propagate plasmids. Agrobacterium tumefaciens AGL1 [29] was used as a T-DNA donor for the transformation of the $v p 1$ gene into T. reesei Rut-C30 and was grown in LB medium at $28{ }^{\circ} \mathrm{C}$ under shaking conditions $(200 \mathrm{rpm})$ for $36 \mathrm{~h}$ with hygromycin $(100 \mathrm{mg} / \mathrm{mL})$ as a selection 
marker. Two-day-old cultures of G. lucidum strain RMK1 and T. reesei strain Rut-C30 cultivated in potato dextrose broth (PDB) were used for genomic DNA isolation following the cetyltrimethylammonium bromide (CTAB) method [30]. Further details about the materials used in these experimental procedures are provided in the Supplementary Materials.

\subsection{Construction of Cloning Vector}

The binary vector pCambia 1300 (CAMBIA, Canberra, Australia) was used as the backbone for the construction of the plasmid vector and as the recipient for the construction of the T-DNA binary vector. The $h p h$ gene that codes for hygromycin B phosphotransferase was first introduced into the vector under the control of the Aspergillus nidulans trpC promoter and terminator to create the $\mathrm{pCXH}$ vector [31]. The $c b h 1$ promoter Pcbh1 and the $x y n 2$ gene were amplified using the primer pairs of Pcbh1F, Pcbh1R, Xyn2F and Xyn2R (Table S1), respectively, using the T. reesei Rut-C30 genomic DNA as a template. The coding region of the $v p 1$ gene was amplified using G. lucidum RMK1 genomic DNA as a template with the respective forward and reverse primers listed in Table S1. The amplified sequences were separated by agarose gel electrophoresis using a horizontal submarine electrophoresis apparatus (Medox, Chennai, Tamil Nadu, India). The separated sequences of interest were observed under an ultraviolet transilluminator and immediately excised using a sterile blade and purified using Axygen's gel extraction kit. The purified promoter (cbh1), genes ( $x y n 2$ and $v p 1)$ with a $6 \times$ His-tag (at the C-terminus of rVP1), and terminator segments were fused to the linearized pCXH vector at the predetermined cloning site (Xba1) using the In-Fusion HD cloning kit (Bio-Rad). The resulting constructed vector (pCXH-VP1) (Figure S1) was propagated in E. coli Top10 cells and the purified plasmid was transformed into A. tumefaciens AGL1.

\subsection{Transformation of op1 into T. reesei Rut-C30}

Transfer of the vp1-containing vector to T. reesei Rut-C30 was carried out using A. tumefaciensmediated transformation as described previously [31]. Transformed A. tumefaciens AGL1 (carrying the plasmid vector pCXH-VP1) was grown for $36 \mathrm{~h}$ at $28^{\circ} \mathrm{C}$ in LB medium containing kanamycin and carbenicillin. The culture was then diluted in an induction medium (IM) containing $10 \mu \mathrm{L}$ of $200 \mu \mathrm{M}$ acetosyringone (AS) and $400 \mu \mathrm{L}$ of $1 \mathrm{M}$ 2-(N-morpholino) ethanesulphonic acid (MES) to attain an optical density $\left(\mathrm{OD}_{660}\right)$ of 0.15 . The $A$. tumefaciens AGL1 culture was again grown at $28^{\circ} \mathrm{C}$ for $6 \mathrm{~h}$ or until the culture reached an $\mathrm{OD}_{660}$ of 0.6 in IM medium (10 mL, with added AS and MES). In another step, T. reesei Rut-C30 was grown for 7 days and the spores were extracted using $1 \mathrm{~mL}$ of a spore-extraction solution containing Tween $80(0.05 \%)$ and $\mathrm{NaCl}(0.85 \%)$ and the spore concentration was adjusted to $10^{6} / \mathrm{mL}$. Equal volumes of $A$. tumefaciens AGL1 culture and T. reesei Rut-C30 conidia were smeared on an IM plate containing $200 \mu \mathrm{M}$ AS $(50 \mu \mathrm{L})$ and MES $(2 \mathrm{~mL})$ and co-cultured for 2 days at $26{ }^{\circ} \mathrm{C}$ in the dark. The co-cultured plate was supplemented with $1 \mathrm{~mL}$ of saline solution (gently smeared with a sterile glass rod). The smeared co-culture paste was then spread onto PDA medium containing $2 \mathrm{~mL}$ of $10 \%(v / v)$ Triton-X 100, hygromycin $(0.37 \mu \mathrm{M})$, and cefotaxime $(10 \mu \mathrm{M})$, and incubated at $37^{\circ} \mathrm{C}$. Well-distinguished round-shaped colonies appeared after 5 to 7 days of incubation and the colonies were transferred onto 24-well PDA plates (supplemented with hygromycin B [0.37 $\mu \mathrm{M}]$ and cefotaxime [10 $\mu \mathrm{M}$ ] antibiotics at pre-determined concentrations). The integration of the $v p 1$ gene into the genomic DNA of T. reesei Rut-C30 was verified by polymerase chain reaction analysis using the forward and reverse primers of the $v p 1$ gene.

\subsection{Enzyme Activity of rVP1 and Protein Assay}

Experimental details of production and purification of rVP1 using transformed T. reesei Rut-C30 are provided in the Supplementary Materials. Briefly, the crude culture filtrate from 1-week old $T$. reesei Rut-C30 (parent and transformant tVP7) was centrifuged at 12,000× $g$ for 15 min at $4{ }^{\circ} \mathrm{C}$ for the enzyme assay and protein estimation. Protein concentration in both the culture filtrates was estimated using a commercial kit (Bio-Rad DC Protein Assay Kit; Bio-Rad Laboratories, Inc., Hercules, CA, 
USA) in which bovine serum albumin (BSA) served as a protein standard. rVP1 was quantified by measuring the oxidation of phenol red $\left(\mathrm{A}_{610} \varepsilon=22.0 \mathrm{mM}^{-1} \mathrm{~cm}^{-1}\right)$ at $\mathrm{Mn}^{2+}$-independent conditions. The $1.5 \mathrm{~mL}$ reaction mixture contained $0.001 \%(w / v)$ phenol red, $2.5 \mathrm{mM}$ lactate, $0.01 \%(w / v) \mathrm{BSA}$ in a $20 \mathrm{mM}$ sodium acetate buffer ( $\mathrm{pH} 4.5)$. The oxidation reaction was stopped by the addition of $\mathrm{NaOH}$ at a final concentration of $8 \mathrm{mM}$. The measurements were taken in the presence and absence of $\mathrm{H}_{2} \mathrm{O}_{2}$ for measuring the peroxidase-specific activity. Boiled samples of culture filtrates (otherwise the same conditions) were used as blanks. One unit of enzyme activity was equivalent to the amount of enzyme that catalyzed the production of $1 \mu \mathrm{M}$ of oxidation product per $\mathrm{mL}$ of culture filtrate. Additional methodological details for electrophoresis and western blot analyses are provided in the Supplementary Materials (Materials and Methods section).

\subsection{Delignification and Saccharification of Paddy Straw by Transformants and Parent T. reesei Rut-C30}

Fresh paddy straw was collected from a local paddy field (Chennai, Tamil Nadu, India). The composition of cellulose, hemicelluloses, and lignin in the paddy straw was analyzed as described previously [32]. The experiment was carried out in triplicate. To compare the delignification efficiency of transformed T. reesei Rut-C30 strain $\mathrm{tVP7}$, the two paddy straw samples $(0.5 \mathrm{~g} / \mathrm{mL})$ were pre-treated [33] with acid $\left(5 \% w / v \mathrm{H}_{2} \mathrm{SO}_{4}\right)$ and alkali $(5 \% w / v \mathrm{NaOH})$, and a third sample of paddy straw was subjected to simultaneous pre-treatment and saccharification using the culture filtrate of transformed T. reesei Rut-C30 strain tVP7. For pre-treatment, $0.5 \mathrm{~g}$ of paddy straw sample was added with $10 \mathrm{~mL}$ of $5 \%$ $(w / v) \mathrm{NaOH}$ or $\mathrm{H}_{2} \mathrm{SO}_{4}$ solution and incubated at $50{ }^{\circ} \mathrm{C}$ for $2 \mathrm{~h}$ under shaking condition (150 rpm). Then, the pre-treated samples were centrifuged at $3000 \mathrm{~g}$ for $5 \mathrm{~min}$. and washed thrice with water. Before the acid pre-treatment, the sample was autoclaved at $121{ }^{\circ} \mathrm{C}(15 \mathrm{psi})$ for $20 \mathrm{~min}$. The pre-treated pellet was lyophilized and stored at $-20^{\circ} \mathrm{C}$ until used further. About $100 \mathrm{mg} / \mathrm{mL}$ of the lyophilized pre-treated biomass was suspended in acetate buffer $(50 \mathrm{mM}, \mathrm{pH} 4.5)$ in a $2 \mathrm{~mL}$ Eppendorf tube for saccharification. To all three sets of preparations, 3 filter paper units (FPUs) of cellulase enzyme (from parent $T$. reesei Rut-C30) per gram of substrate were added. The saccharification/hydrolysis was carried out at $45{ }^{\circ} \mathrm{C}$ under shaking conditions at $150 \mathrm{rpm}$ for $48 \mathrm{~h}$. The amount of lignin in the pre-treated samples was quantified as described previously [32] to measure the delignification efficiency of different pre-treatments. Saccharification efficiency was estimated by quantifying the production of total reducing sugar (TRS) using the 3,5-dinitrosalicylic acid (DNS) method [34].

\subsection{Scanning Electron Microscopy}

Morphological and structural changes in paddy straw during pre-treatment were observed using SEM. The paddy straw pre-treated with supernatants of transformed and untransformed parent strains were compared with untreated paddy straw. The pre-treated paddy straw residue was washed with water and finally lyophilized for SEM analysis. The dried samples were coated with gold (Polaron Emitech SC7640 sputter coater, UK) and microscopic images were taken at 250X by a PhenomPro desktop SEM (Phenom-World, Eindhoven, The Netherlands) at a voltage of $10 \mathrm{kV}$.

\subsection{Statistical Analysis}

The data obtained in this study are presented as mean \pm standard deviation. The differences between the groups were established using an unpaired Student's $t$-test, while within-group comparisons were performed using the paired Student's $t$-test.

\section{Results}

\subsection{Construction and Transformation of Expression Vector Containing vp 1 into T. reesei Rut-C30}

The expression vector was successfully constructed and the final arrangement of the gene-vector construct (named pCXH-VP1) read like pCXH-Pcbh1-Xyn2-VP1-Ttrpc-pCXH in a circular clock-wise fashion (Figure S1). The transformation of the constructed vector into T. reesei Rut-C30 was confirmed 
through colony PCR and, out of 20 colonies tested, 2 colonies, tVP7 and tVP13, showed successful transformation. The transformation efficiency of T. reesei was calculated to be between 250 and 400 successful transformants per $1 \times 10^{7}$ conidia. This confirmed the successful integration of the vp 1 gene into the chromosomal DNA of T. reesei Rut-C30.

\subsection{Enzyme and Protein Production by Transformants and Parent Strain T. reesei Rut-C30}

To express and purify heterologous rVP1 protein in T. reesei Rut-C30, a $6 \times$ His-tag was introduced to the C-terminus of the rVP1 protein. Both successful transformants (tVP7 and tVP13) were cultivated in fermentation medium along with the parent T. reesei Rut-C30 strain and all culture filtrates were harvested and analyzed for protein quantity and VP activity. The supernatant of transformant tVP7 showed higher enzyme activity with $437 \pm 1.0 \mathrm{U} / \mathrm{L}$ of VP activity and produced $10.52 \pm 0.01 \mathrm{mg} / \mathrm{mL}$ of extracellular protein. The transformant tVP13 produced comparatively less enzyme (384 $\pm 1.08 \mathrm{U} / \mathrm{L})$ and protein $(9.48 \pm 0.02 \mathrm{mg} / \mathrm{mL})$. By comparison, the parent T. reesei Rut-C30 produced $9.08 \pm 0.03 \mathrm{mg} / \mathrm{mL}$ of protein and no VP (Table 1). The filter paper activity (FPA) of the two transformants (tVP7 and tVP13) and parent $T$. reesei Rut-C30 were $14.92 \pm 0.32,12.36 \pm 0.25$, and $13.61 \pm 0.24 \mathrm{U} / \mathrm{mL}$, respectively. This showed that the introduction of the vp1 gene did not affect FPA significantly in tVP7 and tVP13 transformants ( $p=0.154$ and $0.134, t$-test) compared with their parent $T$. reesei Rut-C30 strain.

Table 1. Protein concentration and enzyme activity of parent T. reesei Rut-C30 and transformed T. reesei Rut-C30 strains tVP7 and tVP13.

\begin{tabular}{ccccc}
\hline Strain & $\begin{array}{c}\text { Extracellular } \\
\mathbf{( m g / m L )}\end{array}$ & $\begin{array}{c}\text { Protein VP } \\
\text { Activity (U/L) }\end{array}$ & FPA (U/mL) & $\begin{array}{c}\text { VP-Specific } \\
\text { Activity (U/mg) }\end{array}$ \\
\hline T. reesei Rut-C30 & $09.08 \pm 0.03$ & $\mathrm{ND}$ & $13.61 \pm 0.24$ & ND \\
tVP7 & $10.52 \pm 0.01$ & $437 \pm 1.0$ & $14.92 \pm 0.32$ & $41.53 \pm 1.02^{* * *}$ \\
tVP13 & $09.48 \pm 0.02$ & $384 \pm 1.08$ & $12.36 \pm 0.25$ & $40.50 \pm 1.04^{* * *}$ \\
\hline
\end{tabular}

Values represent data obtained from triplicate assays. FPA, filter paper activity; ND, not detectable; ${ }^{* * *} p<0.001$, compared with the parent $T$. reesei Rut-C30 strain.

The successful expression of rVP1 was confirmed using western blot analysis by analyzing the extracellular proteins of the two positive transformants (tVP7and tVP13 strain) and comparing them with the parent $T$. reesei Rut-C30 strain. Western blot analysis showed a clear band at a molecular weight of $39 \mathrm{kDa}$ in the tVP7 and tVP13 transformants carrying the G. lucidum-derived vp1 gene, which is close to the theoretical value of $\sim 37 \mathrm{kDa}$ (w/o VP1 signal peptide) calculated from the deduced amino acid sequences for the vp1 gene from G. lucidum RMK1 (Figure 1, left panel). The rVP1 enzyme was purified using single-step purification and Ni-NTA affinity column chromatography (Qiagen). The purified rVP1 exhibited 4.68-fold purity compared with the crude culture filtrate (Table 1). The purity of the final rVP1 preparation was analyzed by SDS-PAGE followed by silver nitrate staining [35], which confirmed the presence of a single polypeptide chain with a relative molecular mass of $39 \mathrm{kDa}$ (Figure 1, right panel). 


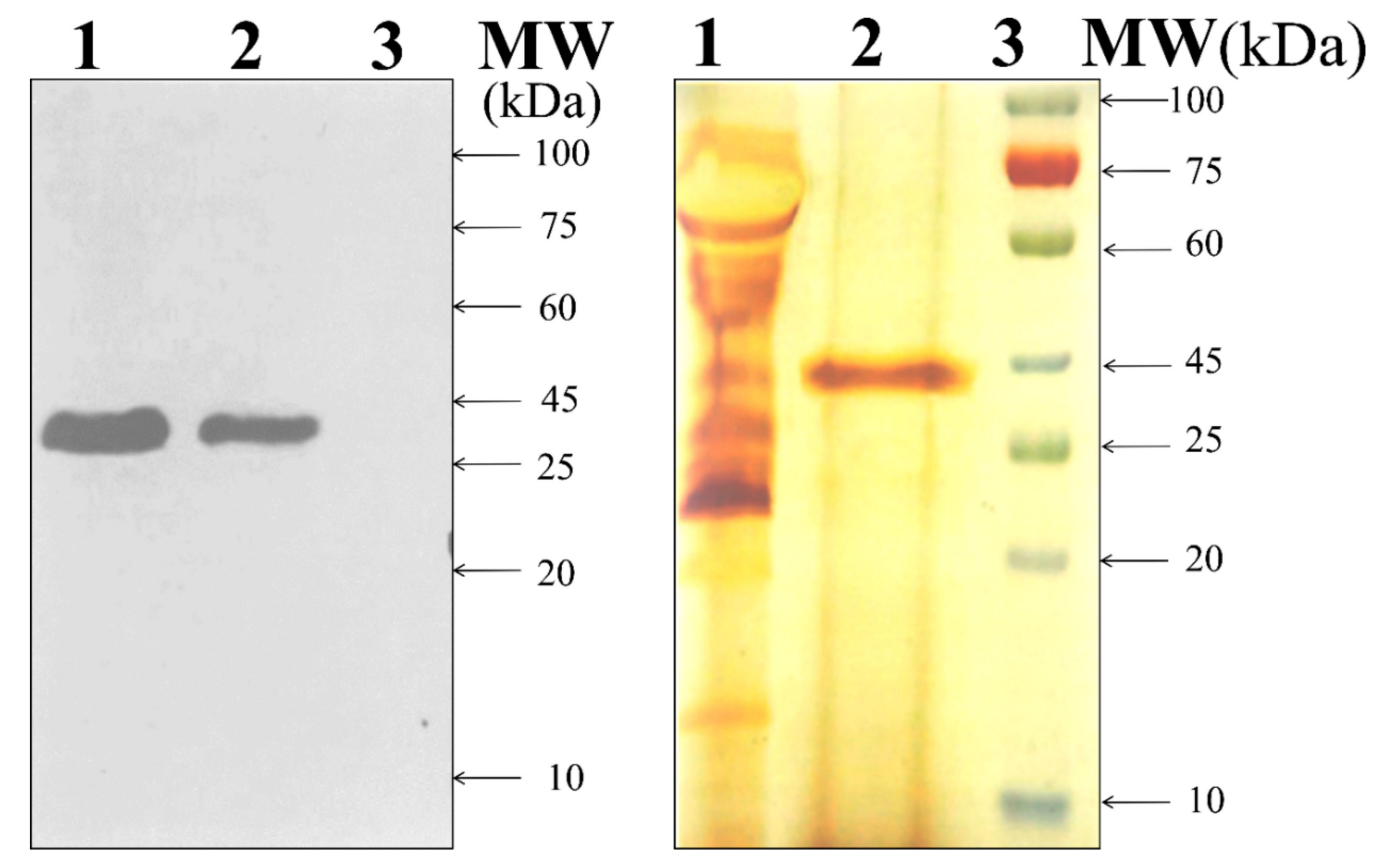

Figure 1. Molecular weight determination of rVP1. Left panel: Western blot analysis of extracellular recombinant G. lucidum-derived protein (rVP1) expressed using transformed T. reesei Rut-C30 strains tVP7 and tVP13. Lane 1, crude culture supernatant of transformant tVP7; lane 2, crude culture supernatant of transformant $\mathrm{tVP13}$; lane 3, crude culture supernatant of the parent strain (T. reesei Rut-C30); molecular weight (MW) in kDa; right panel: molecular weight determination of rVP1 from transformed T. reesei Rut-C30 strain tVP7. Lane 1, crude culture supernatant from transformant tVP7; lane 2, purified rVP1 from transformant tVP7; lane 3, pre-stained protein marker (in kDa).

\subsection{Delignification and Saccharification Efficiency of Transformed T. reesei Rut-C30}

Cellulose was the most abundant component in the paddy straw with a proportion of $43.5 \%$ $\pm 1.2 \%$, followed by hemicellulose with $23.2 \% \pm 0.4 \%$ proportion. The holocellulose (cellulose and hemicellulose) constituted approximately $66.70 \%$ of the total dry weight of the paddy straw. The paddy straw was estimated to contain $16.1 \%$ lignin, for which the acid-soluble and acid-insoluble lignin content was $3.8 \% \pm 0.1 \%$ and $12.3 \% \pm 0.3 \%$, respectively. The amount of ash was estimated to be $11.7 \% \pm 0.4 \%$ of the total dry weight of the paddy straw. The balance of the proportion (to $100 \%$ ) was assumed to be the percentage of silica present in the paddy straw.

The ground paddy straw was initially pre-treated with $\mathrm{NaOH}$ and $\mathrm{H}_{2} \mathrm{SO}_{4}$, followed by simultaneous pre-treatment and saccharification with supernatants of cloned and parent $T$. reesei Rut-C30 culture filtrates. Among the four different tested conditions, paddy straw pre-treated with sulfuric acid exhibited maximum saccharification, with a maximum total reducing sugar of $35.84 \mathrm{mg} / \mathrm{mL}$, followed by $\mathrm{NaOH}$ pre-treatment, which yielded $33.56 \mathrm{mg} / \mathrm{mL}$ of total reducing sugar. The transformed T. reesei Rut-C30 strain $\mathrm{tVP7}$ and parent $T$. reesei Rut-C30 treated paddy straw produced 25.45 and $18.69 \mathrm{mg} / \mathrm{mL}$ of total reducing sugar, respectively (Figure 2A).

Lignin quantification after the different pre-treatments was carried out according to the method cited earlier [32]. The maximum delignification of $46.95 \%$ was achieved during dilute acid pre-treatment $\left(5 \% v / v \mathrm{H}_{2} \mathrm{SO}_{4}\right)$ followed by alkaline pre-treatment $(5 \% w / v \mathrm{NaOH})$, which achieved delignification of $43.72 \%$. The transformed T. reesei Rut-C30 strain tVP7 achieved a delignification efficacy of $32.68 \%$ (Figure 2B). 
A

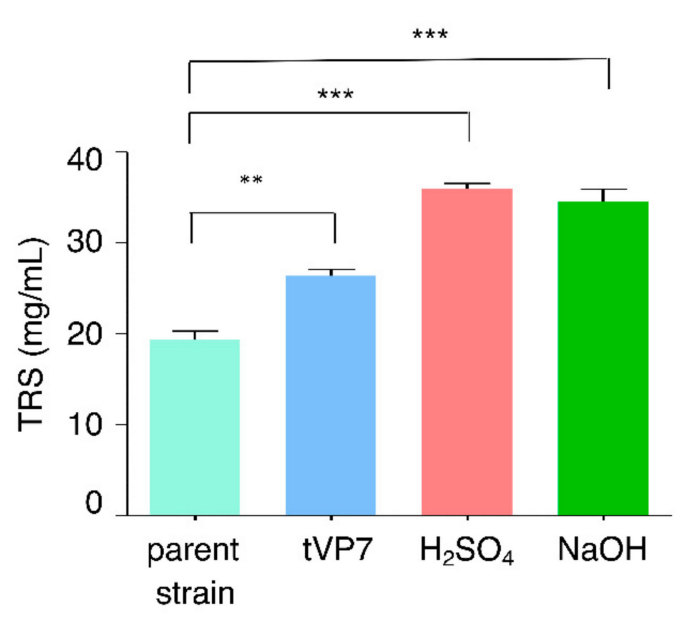

B
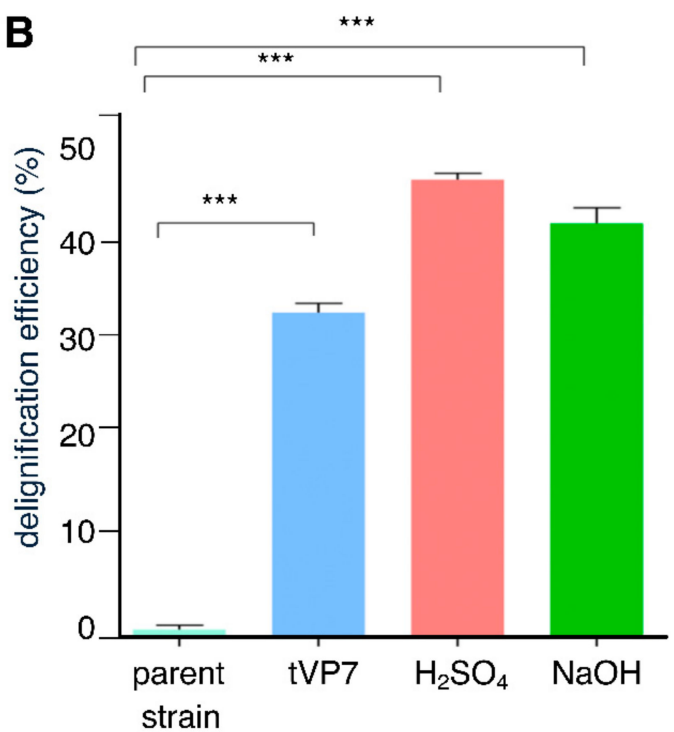

Figure 2. Saccharification and delignification efficiency of transformant tVP7. (A) Saccharification of paddy straw as total reducing sugar (TRS) after different pre-treatments. Values represent data obtained in triplicate assays. $\left({ }^{* *} p<0.01\right.$ and ${ }^{* * *} p<0.001$, compared with the parent strain $T$. reesei Rut-C30); (B) Delignification efficiency of different pre-treatments using paddy straw as lignocellulosic biomass. Values represent data obtained in triplicate assays. ${ }^{* * *} p<0.001$, compared with the parent strain T. reesei Rut-C30).

\subsection{Scanning Electron Microscopic Observation}

The effect of crude culture filtrates of transformed T. reesei Rut-C30 strain tVP7 and parent $T$. reesei Rut-C30 with respect to the control (untreated) on the topology of paddy straw is shown in Figure 3A-C. A close look at untreated paddy straw (Figure 3A) reveals the presence of phytoliths (silica-storing bodies) on an intact epidermis. The treatment of paddy straw with the culture filtrate of the parent strain exhibited signs of saccharification, which is indicated by the rugged and irregular surface and the absence of phytoliths (Figure 3B). The crude extract of transformed T. reesei Rut-C30 (tVP7) exhibited severe distortion of several layers of paddy straw because of the saccharification and delignification due to the presence of rVP1 (Figure 3C).
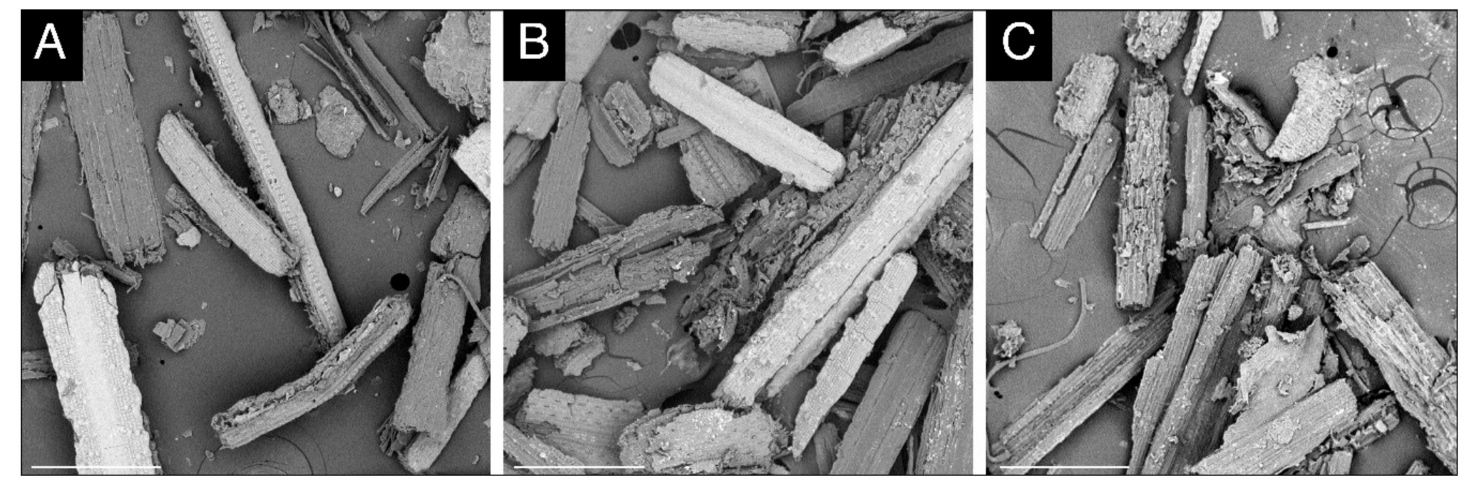

Figure 3. SEM analysis of paddy straw (representative pictures are shown): (A) untreated paddy straw, (B) paddy straw treated with culture filtrate of parent T. reesei Rut-C30, and (C) paddy straw treated with culture filtrate of transformed T. reesei Rut-C30 strain tVP7. Scale bars represent $300 \mu \mathrm{m}$.

\section{Discussion}

Trichoderma reesei is one of the most important filamentous fungi among model organisms for the production of recombinant protein and in plant biomass degradation [36]. After the discovery of transformation techniques $[37,38]$, various proteins of fungal and non-fungal origin have been 
successfully expressed in T. reesei $[39,40]$; the production of fungal proteins, in particular, was more efficient than that of mammalian proteins. For instance, fungal proteins such as laccase, lipase, xylanase, and glucose oxidase were expressed using the $c b h 1$ promoter at levels of $100 \mathrm{mg} / \mathrm{L}$ and several grams per liter in shake-flask and fermentation cultures, respectively [26,41-43]. One of the most advantageous properties of $T$. reesei is that it does not hyperglycosylate proteins. Trichoderma reesei produces significantly less protease than Aspergillus nidulans [44], allowing the former to be used as a host for heterologous gene expression.

In the present study, we cloned the $v p 1$ gene from G. lucidum RMK1 and expressed rVP1 in $T$. reesei Rut-C30. Heterologous expression of the $v p 1$ gene was carried out under the control of the strong wild-type $c b h 1$ promoter as suggested by earlier reports [45]. The $c b h 1$ promoter encodes cellulase in $T$. reesei and is a default promoter for heterologous expression of proteins in T. reesei $[46,47]$. The use of the $c b h 1$ promoter was further supported by a recent study [48] that claimed successful over-expression of Aspergillus oryzae acetyl xylan esterase in T. reesei under the control of the cbh1 promoter.

Lack of a generous cell wall facilitating DNA transfer makes filamentous fungi difficult to use in transformation experiments [49]. Owing to the complex processes involved in protoplast fusion, a research group found $A$. tumefaciens AGL1 to be efficient for the transformation of T-DNA to the host through a co-cultivation method and AS amendment [50]. Here, we applied the same method to transform the $v p 1$ gene from A. tumefaciens AGL1 to T. reesei Rut-C30 with an efficiency of 250 to 400 successful transformants per $1 \times 10^{7}$ conidia.

We attempted to express $v p 1$ for the secretion of rVP1 using the native signal peptide, but the transformants failed to secrete the protein extracellularly. In most cases of heterologous protein expression, the poor native signal peptide in the gene of interest explained the host inefficiency in secreting the gene product, even after successful transformation [51]. A recent report suggested that the fusion of the xyn2 gene to the gene of interest is a novel idea for the successful secretion of the gene product, especially for heterologous expression of genes using T. reesei as the host [48]. Accordingly, we fused the T. reesei $x y n 2$ gene with the G. lucidum $v p 1$ gene. The product rVP1 enzyme was secreted extracellularly upon post-translational cleavage from XYN2 during fermentation by the transformants tVP7 and tVP13, which are absent in the parent T. reesei Rut-C30 strain, as confirmed by western blot analysis. Our purified rVP1 enzyme measured $39 \mathrm{kDa}$ in the purified gel, a size similar to the native VP1 and suggestive of proper processing in the host system. While other researchers have reported a VP larger than ours, a purified VP with a molecular mass of $38 \mathrm{kDa}$, which is closer in size to our purified enzyme, has also been reported [52].

Homologous and heterologous expression of VP has been studied in a variety of prokaryotic and eukaryotic hosts (Table 2) [19,46,52-65]. Expression of Bjerkandera adusta VP in prokaryotic E. coli BL21 (DE3) yielded $322 \mathrm{U} / \mathrm{L}$ of rVP [58]. However, expression of Pleurotus eryngii VP in eukaryotic Aspergillus nidulans and $A$. niger resulted in a yield of $466 \mathrm{U} / \mathrm{L}$ and $412 \mathrm{U} / \mathrm{L}$ active enzymes, respectively [59]. The heterologous expression of Pleurotus eryngii VP in Phanerochaete chrysosporium [63] produced 20 $\mathrm{U} / \mathrm{mL}$ of enzyme, the largest quantity of VP by heterologous expression reported to date. However, no research has been carried out on the expression of a VP gene in T. reesei. In our investigation, we obtained a maximum rVP1 enzyme production of $437 \mathrm{U} / \mathrm{L}$ from our transformant $\mathrm{tVP7}$. The use of the $c b h 1$ promoter increased the efficiency of rVP1 production in T. reesei Rut-C30. 
Table 2. Comparative details of versatile peroxidase (VP) cloned in different prokaryotic and eukaryotic expression hosts.

\begin{tabular}{|c|c|c|c|c|c|}
\hline Source & Host & Vector & Promoter & Enzyme Yield & Reference \\
\hline Physisporinus vitreus & E. coli BL21(DE3) & pET-28a(+) & default & $18 \mathrm{mg} / \mathrm{L}$ & [19] \\
\hline Pleurotus eryngii & Emerciella nidulans & - & alc $A$ & $165 \mathrm{U} / \mathrm{L}$ & [46] \\
\hline Pleurotus sapidus & $\begin{array}{c}\text { Hansenula polymorpha } \\
\text { RB11 }\end{array}$ & pFPMT121 & default & $\begin{array}{l}1.80 \pm 0.10 \mathrm{U} / \mathrm{mg} \\
\text { specific activity }\end{array}$ & {$[52]$} \\
\hline Pleurotus eryngii & Aspergillus nidulans & palcA1 & alc $A$ & $294.3 \mathrm{mg}$ & [53] \\
\hline Pleurotus eryngii & E. coli W3110 & pFFLAG1 & tac & - & [54] \\
\hline Pleurotus ostreatus & Pleurotus ostreatus & pIpM2g & sdi I & $1.5 \mathrm{mg} / \mathrm{L}$ & [55] \\
\hline Pleurotus ostreatus & Pleurotus ostreatus & pIpMc & sdi I & $370 \mathrm{mU} / \mathrm{mL}$ & [56] \\
\hline Pleurotus eryngii & E. coli W3110 & pFFLAG1 & tac & $5.5 \mathrm{mg} / \mathrm{L}$ & [57] \\
\hline Bjarkendra adjusta & E. coli BL21(DE3) & $\begin{array}{c}\text { pET-32b }(+) \text { and } \\
\text { pET- } 19 b(+)\end{array}$ & default & $322 \mathrm{U} / \mathrm{L}$ & [58] \\
\hline Pleurotus eryngii & $\begin{array}{l}\text { Aspergillus nidulans, } \\
\text { Aspergillus niger }\end{array}$ & PAN7-1 & alc $A$ & $\begin{array}{c}466 \mathrm{U} / \mathrm{L} \text { (A. nidulans); } \\
412 \mathrm{U} / \mathrm{L} \text { (A. niger) }\end{array}$ & [59] \\
\hline Pleurotus eryngii & E. coli $\mathrm{W} 3110$ & pFLAG-VPL2 & default & - & {$[60]$} \\
\hline Pleurotus eryngii & E. coli BL21(DE3) & $\begin{array}{c}\text { pET-28a }(+) \text { and } \\
\text { pET-32a(+) }\end{array}$ & default & $12.5 \mathrm{mg} / \mathrm{L}$ & [61] \\
\hline Pleurotus ostreatus & Pleurotus ostreatus & pTM1 & $\beta$-tubulin promoter & $96 \mathrm{mU} / \mathrm{mg}$ substrate & [62] \\
\hline Pleurotus eryngii & $\begin{array}{l}\text { Phanerochaete } \\
\text { chrysosporium }\end{array}$ & Ppchph & gpd & $20 \mathrm{U} / \mathrm{mL}$ & [63] \\
\hline Moniliophthora roreri & Pichia pastoris & pPICZaA & aox1 & $295 \mathrm{mg} / \mathrm{L}$ & [64] \\
\hline Irpex consors & E. coli Top 10 & 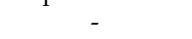 & - & $>250 \mathrm{U} / \mathrm{L}$ & [65] \\
\hline Ganoderma lucidum & T. reesei Rut-C30 & pCambia-1300 & $\operatorname{cbh} 1$ & $437 \mathrm{U} / \mathrm{L}$ & $\begin{array}{l}\text { present } \\
\text { study }\end{array}$ \\
\hline
\end{tabular}

-: information not provided.

Paddy straw, one of the most common forms of agricultural waste in Asia, provides an opportunity for sustainable bioethanol production due to its high potential for total reducing sugar (in terms of high cellulose content) and low lignin content [66]. Despite a lower content of lignin, pre-treatment is necessary for efficient saccharification of paddy straw and further fermentation to ethanol. For example, only $20 \%$ of the total reducing sugar can be extracted from native paddy straw by enzymatic hydrolysis without pre-treatment [67]. Pre-treatment can therefore significantly improve the saccharification yield of the paddy straw [68]. In our experiment, paddy straw saccharified with supernatant of parent T. reesei Rut-C30 yielded $18.69 \mathrm{mg} / \mathrm{mL}$ of reducing sugar. The transformed T. reesei Rut-C 30 strain tVP7 improved the yield of reducing sugar to $25.45 \mathrm{mg} / \mathrm{mL}$. An earlier study obtained $268.5 \mathrm{mg} / \mathrm{g}$ reducing sugar from $4 \% \mathrm{NaOH}$-pre-treated paddy straw on saccharification with $\mathrm{T}$. reesei Rut-C30 with a saccharification rate of $54.3 \%$ [69]. In this study, we obtained $33.56 \mathrm{mg} / \mathrm{mL}$ of reducing sugar by pre-treating paddy straw with $5 \% \mathrm{NaOH}$ (Figure $2 \mathrm{~A}$ ). A recent study reported a 4.5 -times improvement in glucose yield $(43.5 \mathrm{~g} / \mathrm{L})$ from paddy straw $(9.5 \mathrm{mg} / \mathrm{mL})$ treated with $0.5 \mathrm{M} \mathrm{Na}_{2} \mathrm{CO}_{3}$ at $180^{\circ} \mathrm{C}$ for 120 min compared with untreated paddy straw [70].

We obtained the greatest amount of reducing sugar (approximately $35.84 \mathrm{mg} / \mathrm{mL}$ ) in the acid pre-treatment and saccharification using the T. reesei Rut-C30 culture filtrate (Figure 2A). Consistent with our results, a previous study [71] obtained $359 \mathrm{mg}$ of reducing sugar per gram of paddy straw at optimized conditions (pre-treatment: $0.5 \%$ sulfuric acid for $60 \mathrm{~min}$ at $121{ }^{\circ} \mathrm{C}$ in an autoclave; saccharification: $40 \mathrm{FPU} / \mathrm{g}$ enzymes, $17.50 \%$ substrate, at $50{ }^{\circ} \mathrm{C}$ for $72 \mathrm{~h}$ ) that differed from ours. Another pilot-scale study that applied diluted acid pre-treatment to rice straw obtained $115.2 \mathrm{mg} / \mathrm{mL}$ of total reducing sugar at conditions of $0.35 \%(w / v) \mathrm{H}_{2} \mathrm{SO}_{4}$ and $162{ }^{\circ} \mathrm{C}$ for $10 \mathrm{~min}$ [72]. Our observations were corroborated with SEM analysis of treated and untreated paddy straw. SEM observations of paddy straw treated with culture filtrates of transformed tVP7 and parent $T$. reesei Rut-C30 revealed severely distorted topology (Figure 3). The absence of such modifications in untreated and parent-treated paddy straws confirmed the efficiency of our transformed T. reesei Rut-C30 strain tVP7. Similar structures of phytoliths on an intact epidermis and rugged cell structures were reported with untreated and $\mathrm{NaOH}$ treated paddy straw surfaces, respectively, under SEM observation [73].

Our delignification study revealed the transformant tVP7 efficiently removed lignin, although not as effective as the acid and alkali pre-treatments. Other teams have reported higher levels of 
delignification, using acid and alkali methods [70,74]. However, the improved saccharification yield and delignification reported in other studies were only due to the application of higher temperatures during pre-treatment, and applying high temperatures may severely affect production costs. Although chemical pre-treatments produced more fermentable sugars than the cloned tVP7 and parent $T$. reesei Rut-C30 strains-derived supernatants (with paddy straw as a substrate), the fermentation efficiency of $\mathrm{H}_{2} \mathrm{SO}_{4}(80.17 \%)$ and $\mathrm{NaOH}(84.08 \%)$ treatments were relatively low (unpublished observation), likely due to the production of toxic by-products [75]. Pre-treatment of paddy straw increases the accessibility and surface area of cellulose by lignin modification or degradation, leading to enhanced saccharification efficiency. Incidentally, our transformed T. reesei Rut-C30 strain tVP7 hydrolysate achieved a maximum fermentation efficiency $(93.85 \%)$, followed by its parent $T$. reesei Rut-C30 strain (87.99\%) (unpublished observation), emphasizing the importance of the biological pre-treatment process to improve the efficiency of fermentation and ethanol production.

\section{Conclusions}

In the current study, the VP1 encoding gene (vp1) was cloned from G. lucidum RMK1 and heterologously expressed in $T$. reesei Rut-C30 under the control of a strong and inducible $c b h 1$ promoter. The production of rVP1 by the transformed T. reesei Rut-C30 strain tVP7 improved the saccharification efficiency of $T$. reesei Rut-C30, which lacks efficient endogenous ligninolytic enzyme activity. These results make rVP1 a promising candidate for the efficient degradation of lignocellulosic biomasses (Figure 4). Such a genetic bioengineering approach could also provide an opportunity to heterologously express rVP1 in other industrial cellulase producing strains and reduce the costs of ligninolytic enzyme production for biofuel applications and lignin valorization.

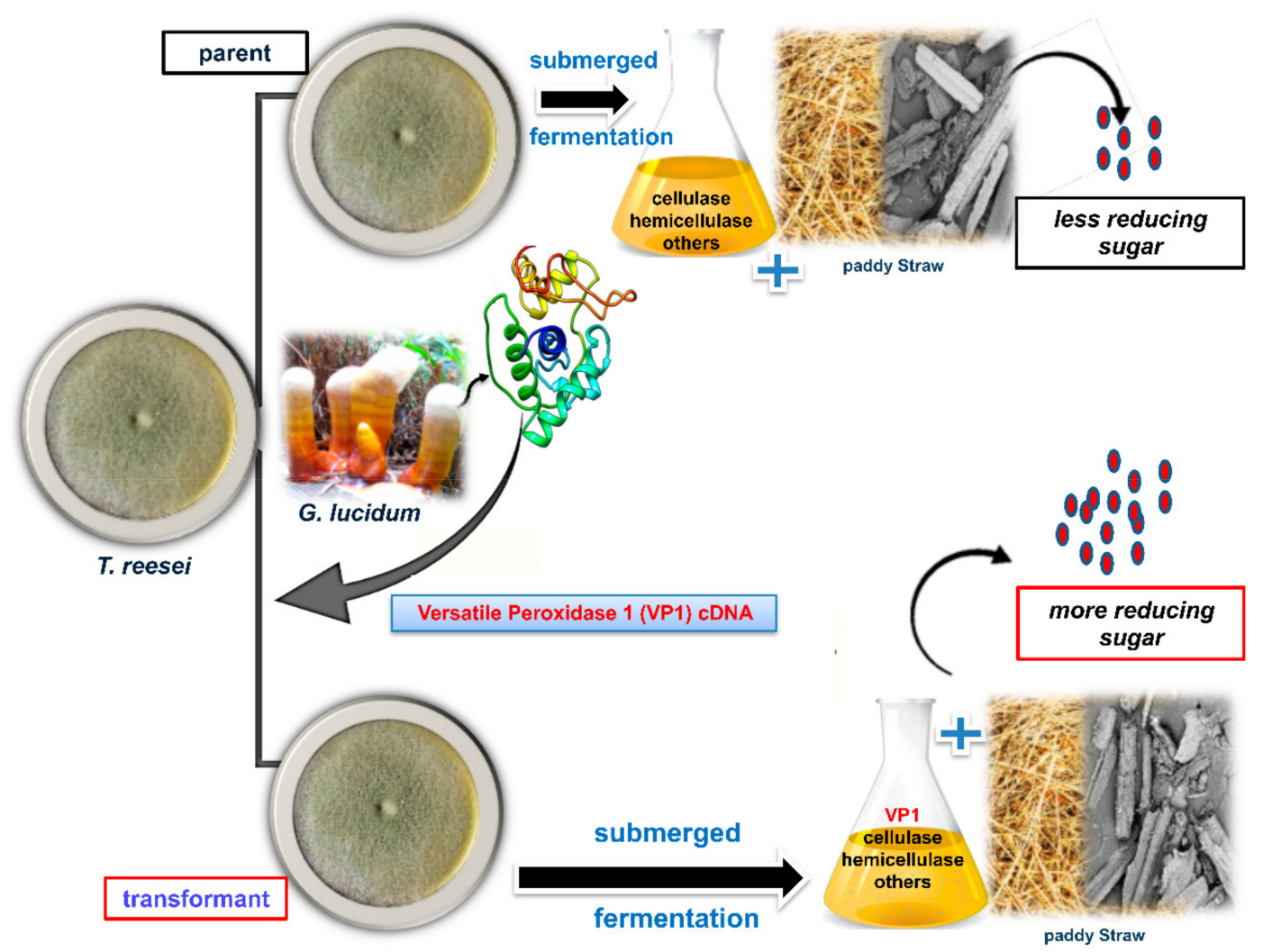

Figure 4. A schematic summary showing increased reducing sugar yield for improved bioethanol production using $T$. reesei through a genetic bioengineering approach.

Supplementary Materials: Supplementary Materials can be found at http://www.mdpi.com/2076-2607/8/2/159/s1. 
Author Contributions: Conceptualization and design, K.H. and K.P.T.; methodology, R.M.G., T.M., J.R., and K.P.T.; formal analysis, R.M.G., T.M., and J.R.; investigation, R.M.G., T.M., and J.R.; data curation, R.M.G., T.M., J.R., K.H., and K.P.T.; writing-original draft preparation, R.M.G. and T.M.; writing—review and editing, K.H. and K.P.T.; supervision, K.P.T.; project administration, K.P.T.; funding acquisition, K.H. and K.P.T. All authors listed have read and approved the manuscript for publication.

Funding: This research received no external funding.

Acknowledgments: The authors would like to thank the Director, Centre for Advanced Studies in Botany, University of Madras, Guindy Campus, Chennai, India for the laboratory support. The authors also extend their thanks to the Analytical Testing Facilities, CSIR-Central Leather Research Institute, Chennai, India for facilitating SEM analysis.

Conflicts of Interest: The authors declare no conflict of interest.

\section{References}

1. Gupta, A.; Verma, J.P. Sustainable bio-ethanol production from agro-residues: A review. Renew. Sust. Energ. Rev. 2015, 41, 550-567. [CrossRef]

2. Siddique, A.; Gul, A.; Irfan, M.; Nadeem, M.; Syed, Q. Comparison of different pretreatment methods for efficient conversion of bagasse into ethanol. Biofuels 2017, 8, 135-141. [CrossRef]

3. Saini, J.K.; Saini, R.; Tewari, L. Lignocellulosic agriculture wastes as biomass feedstocks for second-generation bioethanol production: Concepts and recent developments. 3 Biotech. 2015, 5, 337-353. [CrossRef] [PubMed]

4. Kim, D. Physico-chemical conversion of lignocellulose: Inhibitor effects and detoxification strategies: A mini review. Molecules 2018, 23, 309. [CrossRef] [PubMed]

5. Pei, Y.; Li, Y.; Zhang, Y.; Yu, C.; Fu, T.; Zou, J.; Tu, Y.; Peng, L.; Chen, P. G-lignin and hemicellulosic monosaccharides distinctively affect biomass digestibility in rapeseed. Bioresour. Technol. 2016, 203, 325-333. [CrossRef] [PubMed]

6. Nguyen, T.Y.; Cai, C.M.; Kumar, R.; Wyman, C.E. Overcoming factors limiting high-solids fermentation of lignocellulosic biomass to ethanol. Proc. Natl. Acad. Sci. USA. 2017, 114, 11673-11678. [CrossRef]

7. Wang, Y.; Fan, C.; Hu, H.; Li, Y.; Sun, D.; Wang, Y.; Peng, L. Genetic modification of plant cell walls to enhance biomass yield and biofuel production in bioenergy crops. Biotechnol. Adv. 2016, 34, 997-1017. [CrossRef]

8. Chandra, R.P.; Bura, R.; Mabee, W.E.; Berlin, A.; Pan, X.; Saddler, J.N. Substrate pretreatment: The key to effective enzymatic hydrolysis of lignocellulosics? Adv. Biochem. Eng. Biotechnol. 2007, 108, 67-93.

9. Mosier, N.; Wyman, C.; Dale, B.; Elander, R.; Lee, Y.Y.; Holtzapple, M.; Ladisch, M. Features of promising technologies for pretreatment of lignocellulosic biomass. Bioresour. Technol. 2005, 96, 673-686. [CrossRef]

10. Pienkos, P.T.; Zhang, M. Role of pretreatment and conditioning processes on toxicity of lignocellulosic biomass hydrolysates. Cellulose 2009, 16, 743-762. [CrossRef]

11. Janusz, G.; Pawlik, A.; Sulej, J.; Swiderska-Burek, U.; Jarosz-Wilkolazka, A.; Paszczynski, A. Lignin degradation: Microorganisms, enzymes involved, genomes analysis and evolution. FEMS Microbiol. Rev. 2017, 41, 941-962. [CrossRef] [PubMed]

12. Hammel, K.E.; Cullen, D. Role of fungal peroxidases in biological ligninolysis. Curr. Opin. Plant. Biol. 2008, 11, 349-355. [CrossRef] [PubMed]

13. Knezevic, A.; Stajic, M.; Jovanovic, V.M.; Kovacevic, V.; Cilerdzic, J.; Milovanovic, I.; Vukojevic, J. Induction of wheat straw delignification by Trametes species. Sci. Rep. 2016, 6, 26529. [CrossRef] [PubMed]

14. Manavalan, T.; Manavalan, A.; Heese, K. Characterization of lignocellulolytic enzymes from white-rot fungi. Curr. Microbiol. 2015, 70, 485-498. [CrossRef] [PubMed]

15. Pollegioni, L.; Tonin, F.; Rosini, E. Lignin-degrading enzymes. FEBS J. 2015, 282, 1190-1213. [CrossRef] [PubMed]

16. Knop, D.; Yarden, O.; Hadar, Y. The ligninolytic peroxidases in the genus Pleurotus: Divergence in activities, expression, and potential applications. Appl. Microbiol. Biotechnol. 2015, 99, 1025-1038. [CrossRef]

17. Rodríguez, E.; Nuero, O.; Guillén, F.; Martínez, A.T.; Martínez, M.J. Degradation of phenolic and non-phenolic aromatic pollutants by four Pleurotus species: The role of laccase and versatile peroxidase. Soil Biol. Biochem. 2004, 36, 909-916. [CrossRef]

18. Kong, W.; Fu, X.; Wang, L.; Alhujaily, A.; Zhang, J.; Ma, F.; Zhang, X.; Yu, H. A novel and efficient fungal delignification strategy based on versatile peroxidase for lignocellulose bioconversion. Biotechnol. Biofuels 2017, 10, 218. [CrossRef] 
19. Liu, J.; Zhang, S.; Shi, Q.; Wang, L.; Kong, W.; Yu, H.; Ma, F. Highly efficient oxidation of synthetic and natural lignin-related compounds by Physisporinus vitreus versatile peroxidase. Int. Biodeterior. Biodegradation 2019, 136, 41-48. [CrossRef]

20. Sun, A.; Peterson, R.; Te'o, J.; Nevalainen, H. Expression of the mammalian peptide hormone obestatin in Trichoderma reesei. Nat. Biotechnol. 2016, 33, 99-106. [CrossRef]

21. Rosgaard, L.; Pedersen, S.; Langston, J.; Akerhielm, D.; Cherry, J.R.; Meyer, A.S. Evaluation of minimal Trichoderma reesei cellulase mixtures on differently pretreated Barley straw substrates. Biotechnol. Prog. 2007, 23, 1270-1276. [CrossRef] [PubMed]

22. Kubicek, C.P.; Mikus, M.; Schuster, A.; Schmoll, M.; Seiboth, B. Metabolic engineering strategies for the improvement of cellulase production by Hypocrea jecorina. Biotechnol. Biofuels 2009, 2, 19. [CrossRef] [PubMed]

23. Ahamed, A.; Vermette, P. Enhanced enzyme production from mixed cultures of Trichoderma reesei RUT-C30 and Aspergillus niger LMA grown as fed batch in a stirred tank bioreactor. Biochem. Eng. J. 2008, 42, 41-46. [CrossRef]

24. Saloheimo, M.; Niku-Paavola, M.L.; Knowles, J.K. Isolation and structural analysis of the laccase gene from the lignin-degrading fungus Phlebia radiata. J. Gen. Microbiol. 1991, 137, 1537-1544. [CrossRef]

25. Dong, X.; Qin, L.; Tao, Y.; Huang, J.; Dong, Z. [Overexpression and characterization of a laccase gene from Pleurotus ostreatus in Trichoderma reesei]. Wei Sheng Wu Xue Bao 2012, 52, 850-856.

26. Zhao, J.; Zeng, S.; Xia, Y.; Xia, L. Expression of a thermotolerant laccase from Pycnoporus sanguineus in Trichoderma reesei and its application in the degradation of bisphenol A. J. Biosci. Bioeng. 2018, 125, 371-376. [CrossRef]

27. Singh, A.; Taylor, L.E.; Vander Wall, T.A.; Linger, J.; Himmel, M.E.; Podkaminer, K.; Adney, W.S.; Decker, S.R. Heterologous protein expression in Hypocrea jecorina: A historical perspective and new developments. Biotechnol. Adv. 2015, 33, 142-154. [CrossRef]

28. Manavalan, T.; Manavalan, A.; Thangavelu, K.P.; Heese, K. Characterization of optimized production, purification and application of laccase from Ganoderma lucidum. Biochem. Eng. J. 2013, 70, 106-114. [CrossRef]

29. Lazo, G.R.; Stein, P.A.; Ludwig, R.A. A DNA transformation-competent Arabidopsis genomic library in Agrobacterium. Nat. Biotechnol. 1991, 9, 963-967. [CrossRef]

30. Moller, E.M.; Bahnweg, G.; Sandermann, H.; Geiger, H.H. A simple and efficient protocol for isolation of high molecular weight DNA from filamentous fungi, fruit bodies, and infected plant tissues. Nucleic Acids Res. 1992, 20, 6115-6116. [CrossRef]

31. Ma, L.; Zhang, J.; Zou, G.; Wang, C.; Zhou, Z. Improvement of cellulase activity in Trichoderma reesei by heterologous expression of a beta-glucosidase gene from Penicillium decumbens. Enzym. Microb. Technol. 2011, 49, 366-371. [CrossRef] [PubMed]

32. Hou, Q.; Li, W.; Ju, M.; Liu, L.; Chen, Y.; Yang, Q.; Wang, J. Separation of polysaccharides from rice husk and wheat bran using solvent system consisting of BMIMOAc and DMI. Carbohydr. Polym. 2015, 133, 517-523. [CrossRef] [PubMed]

33. Xu, N.; Zhang, W.; Ren, S.; Liu, F.; Zhao, C.; Liao, H.; Xu, Z.; Huang, J.; Li, Q.; Tu, Y.; et al. Hemicelluloses negatively affect lignocellulose crystallinity for high biomass digestibility under $\mathrm{NaOH}$ and $\mathrm{H}_{2} \mathrm{SO}_{4}$ pretreatments in Miscanthus. Biotechnol. Biofuels. 2012, 5, 58. [CrossRef] [PubMed]

34. Miller, G.L. Use of dinitrosalicylic acid reagent for determination of reducing sugar. Anal. Chem. 1959, 31, 426-428. [CrossRef]

35. Blum, H.; Beier, H.; Gross, H.J. Improved silver staining of plant proteins, RNA and DNA in polyacrylamide gels. Electrophoresis 1987, 8, 93-99. [CrossRef]

36. Bischof, R.H.; Ramoni, J.; Seiboth, B. Cellulases and beyond: The first 70 years of the enzyme producer Trichoderma reesei. Microb. Cell Factories 2016, 15, 106. [CrossRef]

37. Gruber, F.; Visser, J.; Kubicek, C.P.; de Graaff, L.H. The development of a heterologous transformation system for the cellulolytic fungus Trichoderma reesei based on a pyrG-negative mutant strain. Curr. Genet. 1990, 18, 71-76. [CrossRef]

38. Penttila, M.; Nevalainen, H.; Ratto, M.; Salminen, E.; Knowles, J. A versatile transformation system for the cellulolytic filamentous fungus Trichoderma reesei. Gene 1987, 61, 155-164. [CrossRef] 
39. Nevalainen, H.; Peterson, R. Making recombinant proteins in filamentous fungi- are we expecting too much? Front. Microbiol. 2014, 5, 75.

40. Zhong, Y.; Liu, X.; Xiao, P.; Wei, S.; Wang, T. Expression and secretion of the human erythropoietin using an optimized cbh1 promoter and the native CBH I signal sequence in the industrial fungus Trichoderma reesei. Appl. Biochem. Biotechnol. 2011, 165, 1169-1177. [CrossRef]

41. Rantasalo, A.; Vitikainen, M.; Paasikallio, T.; Jantti, J.; Landowski, C.P.; Mojzita, D. Novel genetic tools that enable highly pure protein production in Trichoderma reesei. Sci. Rep. 2019, 9, 5032. [CrossRef] [PubMed]

42. Li, J.; Wang, J.; Wang, S.; Xing, M.; Yu, S.; Liu, G. Achieving efficient protein expression in Trichoderma reesei by using strong constitutive promoters. Microb. Cell Factories 2012, 11, 84. [CrossRef] [PubMed]

43. Wu, Y.; Sun, X.; Xue, X.; Luo, H.; Yao, B.; Xie, X.; Su, X. Overexpressing key component genes of the secretion pathway for enhanced secretion of an Aspergillus niger glucose oxidase in Trichoderma reesei. Enzyme Microb. Technol. 2017, 106, 83-87. [CrossRef] [PubMed]

44. De Souza, P.M.; Bittencourt, M.L.; Caprara, C.C.; de Freitas, M.; de Almeida, R.P.; Silveira, D.; Fonseca, Y.M.; Ferreira Filho, E.X.; Pessoa Junior, A.; Magalhaes, P.O. A biotechnology perspective of fungal proteases. Braz. J. Microbiol. 2015, 46, 337-346. [CrossRef] [PubMed]

45. Lu-Chau, T.A.; Ruiz-Duenas, F.J.; Camarero, S.; Feijoo, G.; Martinez, M.J.; Lema, J.M.; Martinez, A.T. Effect of $\mathrm{pH}$ on the stability of Pleurotus eryngii versatile peroxidase during heterologous production in Emericella nidulans. Bioprocess. Biosyst. Eng. 2004, 26, 287-293. [CrossRef]

46. Haakana, H.; Miettinen-Oinonen, A.; Joutsjoki, V.; Mäntylä, A.; Suominen, P.; Vehmaanperä, J. Cloning of cellulase genes from Melanocarpus albomyces and their efficient expression in Trichoderma reesei. Enzyme Microb. Technol. 2004, 34, 159-167. [CrossRef]

47. Nevalainen, K.M.; Te'o, V.S.; Bergquist, P.L. Heterologous protein expression in filamentous fungi. Trends Biotechnol. 2005, 23, 468-474. [CrossRef]

48. Manavalan, T.; Liu, R.; Zhou, Z.; Zou, G. Optimization of acetyl xylan esterase gene expression in Trichoderma reesei and its application to improve the saccharification efficiency on different biomasses. Process. Biochem. 2017, 58, 160-166. [CrossRef]

49. Meyer, V. Genetic engineering of filamentous fungi-Progress, obstacles and future trends. Biotechnol. Adv. 2008, 26, 177-185. [CrossRef]

50. Zhang, X.; Xia, L. Expression of Talaromyces thermophilus lipase gene in Trichoderma reesei by homologous recombination at the cbh1 locus. J. Ind. Microbiol. Biotechnol. 2017, 44, 377-385. [CrossRef]

51. Garcia-Ruiz, E.; Gonzalez-Perez, D.; Ruiz-Duenas, F.J.; Martinez, A.T.; Alcalde, M. Directed evolution of a temperature-, peroxide- and alkaline pH-tolerant versatile peroxidase. Biochem. J. 2012, 441, 487-498. [CrossRef] [PubMed]

52. Schüttmann, I.; Bouws, H.; Szweda, R.T.; Suckow, M.; Czermak, P.; Zorn, H. Induction, characterization, and heterologous expression of a carotenoid degrading versatile peroxidase from Pleurotus sapidus. J. Mol. Catal. B Enzym. 2014, 103, 79-84. [CrossRef]

53. Ruiz-Duenas, F.J.; Martinez, M.J.; Martinez, A.T. Molecular characterization of a novel peroxidase isolated from the ligninolytic fungus Pleurotus eryngii. Mol. Microbiol. 1999, 31, 223-235. [CrossRef] [PubMed]

54. Pérez-Boada, M.; Doyle, W.A.; Ruiz-Dueñas, F.J.; Martínez, M.J.; Martínez, A.T.; Smith, A.T. Expression of Pleurotus eryngii versatile peroxidase in Escherichia coli and optimisation of in vitro folding. Enzym. Microb. Technol. 2002, 30, 518-524. [CrossRef]

55. Tsukihara, T.; Honda, Y.; Sakai, R.; Watanabe, T.; Watanabe, T. Exclusive overproduction of recombinant versatile peroxidase $\mathrm{MnP} 2$ by genetically modified white rot fungus, Pleurotus ostreatus. J. Biotechnol. 2006, 126, 431-439. [CrossRef]

56. Tsukihara, T.; Honda, Y.; Watanabe, T.; Watanabe, T. Molecular breeding of white rot fungus Pleurotus ostreatus by homologous expression of its versatile peroxidase MnP2. Appl. Microbiol. Biotechnol. 2006, 71, 114-120. [CrossRef]

57. Ruiz-Dueñas, F.J.; Aguilar, A.; Martínez, M.J.; Zorn, H.; Martínez, Á.T. Gene cloning, heterologous expression, in vitro reconstitution and catalytic properties of a versatile peroxidase. Biocatal. Biotransfor. 2007, 25, 276-285. [CrossRef]

58. Mohorcic, M.; Bencina, M.; Friedrich, J.; Jerala, R. Expression of soluble versatile peroxidase of Bjerkandera adusta in Escherichia coli. Bioresour. Technol. 2009, 100, 851-858. [CrossRef] 
59. Eibes, G.M.; Lu-Chau, T.A.; Ruiz-Dueñas, F.J.; Feijoo, G.; Martinez, M.J.; Martinez, A.T.; Lema, J.M. Effect of culture temperature on the heterologous expression of Pleurotus eryngii versatile peroxidase in Aspergillus hosts. Bioprocess. Biosyst. Eng. 2009, 32, 129-134. [CrossRef]

60. Marques, G.; Gamelas, J.A.F.; Ruiz-Dueñas, F.J.; del Rio, J.C.; Evtuguin, D.V.; Martínez, A.T.; Gutiérrez, A. Delignification of eucalypt kraft pulp with manganese-substituted polyoxometalate assisted by fungal versatile peroxidase. Bioresour. Technol. 2010, 101, 5935-5940. [CrossRef]

61. Bao, X.; Liu, A.; Lu, X.; Li, J.J. Direct over-expression, characterization and $\mathrm{H}_{2} \mathrm{O}_{2}$ stability study of active Pleurotus eryngii versatile peroxidase in Escherichia coli. Biotechnol. Lett. 2012, 34, 1537-1543. [CrossRef] [PubMed]

62. Salame, T.M.; Knop, D.; Tal, D.; Levinson, D.; Yarden, O.; Hadar, Y. Predominance of a versatile-peroxidase-encoding gene, mnp4, as demonstrated by gene replacement via a gene targeting system for Pleurotus ostreatus. Appl. Environ. Microbiol. 2012, 78, 5341-5352. [CrossRef] [PubMed]

63. Coconi-Linares, N.; Magana-Ortiz, D.; Guzman-Ortiz, D.A.; Fernandez, F.; Loske, A.M.; Gomez-Lim, M.A. High-yield production of manganese peroxidase, lignin peroxidase, and versatile peroxidase in Phanerochaete chrysosporium. Appl. Microbiol. Biotechnol. 2014, 98, 9283-9294. [CrossRef] [PubMed]

64. Bao, X.; Huang, X.; Lu, X.; Li, J.J. Improvement of hydrogen peroxide stability of Pleurotus eryngii versatile ligninolytic peroxidase by rational protein engineering. Enzym. Microb. Technol. 2014, 54, 51-58. [CrossRef]

65. Imami, A.; Riemer, S.; Schulze, M.; Amelung, F.; Gorshkov, V.; Rühl, M.; Ammenn, J.; Zorn, H. Depolymerization of lignosulfonates by submerged cultures of the basidiomycete Irpex consors and cloning of a putative versatile peroxidase. Enzyme Microb. Technol. 2015, 81, 8-15. [CrossRef]

66. Sukumaran, R.K.; Surender, V.J.; Sindhu, R.; Binod, P.; Janu, K.U.; Sajna, K.V.; Rajasree, K.P.; Pandey, A. Lignocellulosic ethanol in India: Prospects, challenges and feedstock availability. Bioresour. Technol. 2010, 101, 4826-4833. [CrossRef]

67. Ko, J.K.; Bak, J.S.; Jung, M.W.; Lee, H.J.; Choi, I.-G.; Kim, T.H.; Kim, K.H. Ethanol production from rice straw using optimized aqueous-ammonia soaking pretreatment and simultaneous saccharification and fermentation processes. Bioresour. Technol. 2009, 100, 4374-4380. [CrossRef]

68. Alvira, P.; Tomás-Pejó, E.; Ballesteros, M.; Negro, M.J. Pretreatment technologies for an efficient bioethanol production process based on enzymatic hydrolysis: A review. Bioresour. Technol. 2010, 101, 4851-4861. [CrossRef]

69. Kaur, P.P.; Arneja, J.S.; Singh, J. Enzymic hydrolysis of rice straw by crude cellulase from Trichoderma reesei. Bioresour. Technol. 1998, 66, 267-269. [CrossRef]

70. Salehi, S.M.A.; Karimi, K.; Behzad, T.; Poornejad, N. Efficient conversion of rice straw to bioethanol using sodium carbonate pretreatment. Energy Fuels 2012, 26, 7354-7361. [CrossRef]

71. Kshirsagar, S.D.; Waghmare, P.R.; Chandrakant Loni, P.; Patil, S.A.; Govindwar, S.P. Dilute acid pretreatment of rice straw, structural characterization and optimization of enzymatic hydrolysis conditions by response surface methodology. RSC Adv. 2015, 5, 46525-46533. [CrossRef]

72. Kapoor, M.; Soam, S.; Agrawal, R.; Gupta, R.P.; Tuli, D.K.; Kumar, R. Pilot scale dilute acid pretreatment of rice straw and fermentable sugar recovery at high solid loadings. Bioresour. Technol. 2017, 224, 688-693. [CrossRef] [PubMed]

73. Kaur, K.; Phutela, U.G. Enhancement of paddy straw digestibility and biogas production by sodium hydroxide-microwave pretreatment. Renew. Energy 2016, 92, 178-184. [CrossRef]

74. Asgher, M.; Ahmad, Z.; Iqbal, H.M.N. Alkali and enzymatic delignification of sugarcane bagasse to expose cellulose polymers for saccharification and bio-ethanol production. Ind. Crops. Prod. 2013, 44, 488-495. [CrossRef]

75. Masran, R.; Zanirun, Z.; Bahrin, E.K.; Ibrahim, M.F.; Lai Yee, P.; Abd-Aziz, S. Harnessing the potential of ligninolytic enzymes for lignocellulosic biomass pretreatment. Appl. Microbiol. Biotechnol. 2016, 100, 5231-5246. [CrossRef]

(C) 2020 by the authors. Licensee MDPI, Basel, Switzerland. This article is an open access article distributed under the terms and conditions of the Creative Commons Attribution (CC BY) license (http://creativecommons.org/licenses/by/4.0/). 